\title{
Determinants of Learning Achievements: Empirical Analysis of Seven Schools in Cambodian Primary School
}

\author{
Kaoru Ishiguro ${ }^{1}$ \\ ${ }^{1}$ Graduate School of Economics, Kobe University, Hyogo, Japan \\ Correspondence: Kaoru Ishiguro, Graduate School of Economics, Kobe University, Hyogo, Japan. E-mail: \\ ishiguro@econ.kobe-u.ac.jp
}

Received: November 20, 2017

Accepted: December 12, 2017 Online Published: December 27, 2017

doi:10.5539/jel.v7n2p174

URL: http://doi.org/10.5539/jel.v7n2p174

\begin{abstract}
This paper examines the determinants of learning achievements in Cambodian primary schools. Both student factors and family factors are evaluated. The student factors consist of student age, enrollment age, frequency of homework completion, and number of questions to ask in class. The family factors include the father's educational background, domestic assets, and the student's commute time to school. The school factors are confirmed to influence the learning achievements, but the results are unclear as to what school factors have a concrete influence.
\end{abstract}

Keywords: learning achievement, primary school, willingness to learn, Cambodia

\section{Introduction}

What factors influence primary school students' learning achievements in developing countries? In this article, we use empirical analysis to examine this question for Cambodian primary schools. We collected the data by carrying out field research in February 2015 and February 2016 in Seam Reap Province, Cambodia. We created an arithmetic test and a questionnaire survey for the third-grade students in seven primary schools and collected 420 samples. On the questionnaire survey, we asked about the students' willingness to learn such as questions to ask in class and homework completion, in addition to family factors and school factors.

This article contributes to the literature by dealing with student factors such as willingness to learn, which until now have not frequently been seen as influencing learning achievements in developing countries. There is some debate about learning achievements, with some arguing that school factors are more important (Heyneman \& Loxley, 1983) and some that family factors are (Baker et al., 2002). In this article, we consider the student's willingness to learn as a factor that influences learning achievements, in addition to more conventional factors. The empirical analysis of the determinants for learning achievements in Cambodian primary schools has not been conducted often enough until now. We hope our analysis will serve as an important departure point in this research field.

This article comes to several significant conclusions by considering the student factors in addition to the family factors. The student factors consist of student age, enrollment age, the frequency that homework is completed, and the number of questions to ask in class. The family factors include the father's educational background, domestic assets, and the student's commute time to school. The school factors are confirmed to influence the learning achievements, but the results are unclear as to what school factors have a concrete influence.

This article is organized as follows. In Section 2, we examine previous research for the factors of learning achievements in primary schools of developing countries. In Section 3, we give an overview of the research field, data, variables and basic statistics, and our model. In Section 4, we provide the estimated results. In Section 5, we discuss the school factors and our results in comparison with previous literature. Finally, we summarize our conclusions and explain opportunities for future research.

\section{Literature Review}

Previous literature regarding primary schools in developing countries deal with family factors, school factors, and student factors as the determinants of learning achievements (Hanushek, 1995; Glewwe, 2002; Ammermüller et al., 2005; Glewwe \& Kremer, 2006; Tomita \& Murota, 2010; Glewwe et al., 2011). 
The studies that deal with family factors include Baker et al. (2002), Wößmann (2010), and Ammermüller et al. (2005). In their study for Trends in International Mathematics and Science, Baker et al. (2002) analyzed the learning achievement data of 36 countries and areas in arithmetic and science. They point out that the main factors to influence learning achievements are family factors, and that school factors have little influence. Using the data from Progress in International Reading Literacy carried out in 35 countries in 2001, Wößmann (2010) estimates the educational production functions of Argentina and Colombia. In these two countries, the family factors are accepted as the factors influencing educational performance, and the influence of school factors varies by country.

On the other hand, Glewwe (2002) and Glewwe et al. (2011) survey the literature to determine what school factors influence learning achievements. Glewwe (2002) conducts studies that determine that the use of a textbook and a notebook, a radio education, and a class size all have influence. In addition, Glewwe et al. (2011) point out research articles that assert that the use of teaching materials, school facilities, teacher quality, and homework completion influence educational achievements.

Heyneman \& Loxley (1983) analyze the data from science and arithmetic classes in primary and secondary students in 29 countries, and conclude that the influence of school factors on learning achievements is bigger than that of family factors in developing countries where incomes are low. Hanushek (1995) also argues that school factors influence educational achievements. Following their studies, Tomita \& Murota (2010) analyze the learning achievements using the data from Monitoring Achievement in Lower Primary collected in Malawi in 2004. In support of the Heyneman and Loxley hypothesis, they assert that school factors influence learning achievements in arithmetic and language more than family factors in Malawi.

There are few studies that attach immense importance to the influence of student factors on learning achievements in developing countries. However, Glewwe et al. (2011) points out that having homework or not is related to student factors. If the problems due to family factors (e.g., the lack of a family's economic resources) and school factors (e.g., the lack of school facilities and teaching materials) is resolved as the economic development in the developing countries advances, the student factors that seem to be the determinants of learning achievements in developed countries will become important. In this article, we examine the influence of a student's willingness to learn on the learning achievement in Cambodia, which is one of the world's least developed countries.

In addition to the three factors mentioned above, it is sometimes pointed out that the characteristics of a family and school's local community, as well as the educational and life support provided by international organizations and NGOs, influence educational performance (Glewwe, 2002; Glewwe et al., 2011).

\section{Method}

\subsection{Surveyed Field}

Cambodia is classified as a Least Developed Country (LDC) by the United Nations, and the per capita gross national income (GNI) was 1095 U.S. dollars in 2015. As in Japan, all children are required to enter primary school at the age of 6, go to school for six years, and go to the secondary school for three years (Royal Government of Cambodia, 2003). The educational system is organized in this way, but the enrollment age and school attendance periods vary by child.

Siem Reap is in the northwest of the Tonle Sap lake located in the center of Cambodia and is a tourist city led by Angkor monument groups. It is mainly within the city proper that a lot of tourists gather, and the suburbs are mostly agricultural areas with rural scenery. Based on some indices for the 2014/15 academic year regarding primary school provided by the Ministry of Education, Youth and Sport (2015), we examine the characteristics of Siem Reap Province in all 24 Cambodian provinces and Phnom Penh.

As for the net primary school enrollment ratio of each Cambodian province, the highest ratio is $99.3 \%$ in Kampong Cham, the lowest is $71.1 \%$ in Pailin, and Siem Reap's $94.3 \%$ is the thirteenth best. The survival ratio until senior year in Siem Reap Province is the eleventh best at $81.6 \%$; the Cambodian average is $84.1 \%$, with the highest in Takeo at $97.2 \%$ and the lowest in Ratana Kiri at 62.3\%. These two indices for Siem Reap Province are less than the national average, but they are not remarkably low levels.

However, the repeat ratio in Siem Reap is $7.5 \%$, the third worst of all 24 provinces; the national average is $5.1 \%$, the worst is $11.4 \%$ in Stung Treng, and the best is $2 \%$ in Kep. The dropout ratio in Siem Reap is $12.8 \%$, the fourth worst of all 24 provinces; the national average is $8.3 \%$, the worst is $22.7 \%$ in Ratana Kiri, and the best is $3.6 \%$ in Takeo. The promotion ratio in Siem Reap is $79.7 \%$, the third worst of all 24 provinces; the national 
average is $86.5 \%$, the best is $94.1 \%$ in Phnom Penh, and the worst is $72.2 \%$ in Ratana Kiri. As observed above, these three indices are the third or fourth worst of all 24 provinces.

Therefore, the current situation of primary education in Siem Reap Province is that the net enrollment ratio, which means the opportunity for children to learn in primary school, is the same as the national average. However, as the repeat ratio and the dropout ratio after entering to school are high, there is a severe problem with students advancing to upper school.

\subsection{Data}

We collected the data to use for our analysis from a field survey carried out in February 2015 and in February 2016. We conducted the survey in seven primary schools in Siem Reap Province, where there were 500 schools and 164,236 enrollment students in 2014. The respondents to the survey are 420 third-grade students.

In this survey, we gave questionnaires to the students and the teachers, and an arithmetic achievement test to the students. First, we asked the students and teachers about their family background and school life. Then we proctored a timed achievement test of 25 minutes.

Table 1. Descriptive statistics of score

\begin{tabular}{llllll}
\hline School & Obs & Mean & SD & Min & Max \\
\hline \multirow{2}{*}{ MeB } & 58 & 9.4 & 4.11 & 2 & 18 \\
& $(30,28)$ & $(8.7,10.2)$ & $(4.44,3.57)$ & $(2,4)$ & $(18,18)$ \\
BaN & 47 & 10.0 & 4.25 & 3 & 18 \\
& $(20,27)$ & $(12.7,8.0)$ & $(3.77,3.38)$ & $(6,3)$ & $(18,14)$ \\
PrA & 88 & 11.6 & 5.46 & 1 & 20 \\
& $(52,36)$ & $(14.5,7.4)$ & $(3.42,5.18)$ & $(7,1)$ & $(20,19)$ \\
TaK & 59 & 10.6 & 3.96 & 3 & 18 \\
& $(35,24)$ & $(10.9,10.1)$ & $(3.89,4.01)$ & $(4,3)$ & $(18,17)$ \\
PrE & 60 & 10.0 & 3.94 & 1 & 17 \\
& $(31,29)$ & $(8.6,11.5)$ & $(3.01,4.26)$ & $(2,1)$ & $(15,17)$ \\
KnA & 65 & 10.8 & 4.16 & 1 & 18 \\
KhN & $(18,47)$ & $(10.2,11.1)$ & $(4.62,3.94)$ & $(1,2)$ & $(18,18)$ \\
Total & 43 & 13.7 & 4.89 & 2 & 20 \\
& $(186,234)$ & $(11.3,10.5)$ & $(4.46,4.75)$ & $(1,1)$ & 20 \\
\hline
\end{tabular}

Note. The top number is the total number for the years 2015 and 2016. On the next line, the left number in parentheses is for 2015 , the right is for 2016. KhN data is only for 2016 .

Table 1 contains the results of the arithmetic achievement test that represents the descriptive statistics for 420 third-grade students in seven schools. The upper line expresses the total from 2015 and 2016, the first number in parentheses is the data from 2015, and the second number in parentheses is the data from 2016 year. The KhN data are all from 2016.

Based on Table 1, the results or the arithmetic achievement test can be examined. First, the total average of all schools in 2015 and 2016 is 10.8 points (standard deviation 4.64), the best is KhN's 13.7 points (standard deviation 4.89), and the lowest is MeB's 9.4 points (standard deviation 4.11). Second, there are primary schools that have substantial differences in the average scores between 2015 and 2016. The average scores deteriorate 4.7 points in BaN and 7.1 points in PrA from 2015 to 2016. Third, the class sizes are different depending on both the school and the year. The largest class size is 52 students at PrA in 2015 , the smallest is 18 students at KnA 2015 , and the average of all classes is 32 students.

\subsection{Variables and Basic Statistics}

Table 2 represents the variables and their definitions used for our statistical analysis. The explained variable is the score of the arithmetic test. The explanatory variables consist of the family factors, the student factors, and the school factors. The family factors are classified into the family attributes (educational background of father, parents' occupation, number of siblings, domestic assets such as motorcycles and/or cows, and sources of drinking water) and the student's learning environment (hours of housework, length of commute to school, and school supplies such as textbooks). The student factors contain his or her attributes (age and gender), school attendance (enrollment age and repeat experience), and willingness to learn (homework completion and questions to ask in class). The school factors are dummy variables for the seven schools. 
Table 2. Explanation of variables

\begin{tabular}{|c|c|c|c|}
\hline \multirow{2}{*}{$\begin{array}{l}\text { Variables } \\
\text { Dependent }\end{array}$} & \multicolumn{3}{|l|}{ Definition } \\
\hline & $\begin{array}{l}\text { Learning } \\
\text { achievement }\end{array}$ & Arithmetic Score & \\
\hline \multirow[t]{21}{*}{ Independent } & \multirow[t]{8}{*}{ 1. Family factors } & 1) Family attributes & $\begin{array}{l}\text { Educational record of father (grade } 6 \text { uncompleted: } 1 \text {, grade } 6 \\
\text { completed: } 2 \text {, grade } 9 \text { uncompleted: } 3 \text {, grade } 9 \text { completed: } 4 \text { ) }\end{array}$ \\
\hline & & & Parents' occupation (agriculture: 1, fishery: 2, unemployed: 3 , others: 4) \\
\hline & & & Number of siblings \\
\hline & & & Domestic assets, i.e. motorcycles/cows (yes: 1 , no: 0 ) \\
\hline & & & Water source i.e. wells (yes: 1 , no: 0 ) \\
\hline & & $\begin{array}{l}\text { 2) Learning } \\
\text { environment }\end{array}$ & $\begin{array}{l}\text { Housework time per day ( } 0 \text { minutes: } 1 \text {, under } 60 \text { minutes: } 2 \text {, under } 120 \\
\text { minutes: } 3,120 \text { minutes and over: } 4 \text { ) }\end{array}$ \\
\hline & & & $\begin{array}{l}\text { Commute time to school (under } 30 \text { minutes: } 1 \text {, under } 60 \text { minutes: } 2,60 \\
\text { minutes and over: } 3 \text { ) }\end{array}$ \\
\hline & & & School supplies, i.e., textbooks (have 1 , none 0 ) \\
\hline & \multirow[t]{5}{*}{ 2. Student factors } & 1) Student attributes & Age \\
\hline & & & Gender (male: 1 , female: 0 ) \\
\hline & & 2) School attendance & $\begin{array}{l}\text { Enrollment age ( } 6 \text { years old: } 1,7 \text { years old: } 2,8 \text { years old and over: } 3 \text { ) } \\
\text { Grade repetition (no: } 1 \text {, yes: } 0 \text { ) }\end{array}$ \\
\hline & & 3) Willingness to learn & Homework completion (never: 1 , sometimes: 2 , frequently: 3 ) \\
\hline & & & Questions to ask (never: 1 , sometimes: 2 , frequently: 3 ) \\
\hline & \multirow[t]{7}{*}{ 3. School factors } & MeB dummy & (MeB: 1 , others: 0$)$ \\
\hline & & BaN dummy & (BaN: 1 , others: 0$)$ \\
\hline & & PrA dummy & (PrA: 1 , others: 0 ) \\
\hline & & TaK dummy & (TaK: 1 , others: 0$)$ \\
\hline & & PrE dummy & (PrE: 1 , others: 0 ) \\
\hline & & KnA dummy & (KnA: 1 , others: 0$)$ \\
\hline & & KhN dummy & (KhN: 1, others: 0 ) \\
\hline & 2016-year data & 2016-year dummy & (2016-year: 1, others: 0) \\
\hline
\end{tabular}

Table 3 indicates the basic statistics of the explained variable (test score) and the explanatory variables (family factors, student factors, and school factors).

Table 3. Basic statistics

\begin{tabular}{|c|c|c|c|c|c|}
\hline Variables & Obs & Mean & SD & Min & Max \\
\hline Arithmetic Score & 420 & 10.88 & 4.64 & 1 & 20 \\
\hline Father's educational record & 399 & 2.61 & 1.28 & 1 & 4 \\
\hline Mother's occupation & 396 & 2.08 & 1.42 & 1 & 4 \\
\hline Number of siblings & 404 & 3.21 & 0.56 & 2 & 4 \\
\hline Domestic asset (motorcycle) & 420 & 0.78 & 0.41 & 0 & 1 \\
\hline Domestic asset (cow) & 419 & 0.80 & 0.39 & 0 & 1 \\
\hline Drinking water (well) & 418 & 0.95 & 0.20 & 0 & 1 \\
\hline Housework time per day & 401 & 3.03 & 0.77 & 1 & 4 \\
\hline Commute time to school & 402 & 1.15 & 0.39 & 1 & 3 \\
\hline School supplies (textbook) & 418 & 0.96 & 0.17 & 0 & 1 \\
\hline Age & 416 & 9.48 & 1.17 & 7 & 14 \\
\hline Gender & 420 & 0.51 & 0.49 & 0 & 1 \\
\hline Enrollment age & 400 & 1.89 & 0.47 & 1 & 4 \\
\hline Grade repetition & 409 & 0.73 & 0.43 & 0 & 1 \\
\hline Homework completion & 410 & 2.37 & 0.53 & 1 & 3 \\
\hline Questions to ask & 406 & 2.34 & 0.52 & 1 & 3 \\
\hline $\mathrm{MeB}$ & 420 & 0.13 & 0.34 & 0 & 1 \\
\hline $\mathrm{BaN}$ & 420 & 0.11 & 0.31 & 0 & 1 \\
\hline PrA & 420 & 0.20 & 0.40 & 0 & 1 \\
\hline $\mathrm{TaK}$ & 420 & 0.14 & 0.34 & 0 & 1 \\
\hline PrE & 420 & 0.14 & 0.34 & 0 & 1 \\
\hline $\mathrm{KnA}$ & 420 & 0.15 & 0.36 & 0 & 1 \\
\hline $\mathrm{KhN}$ & 420 & 0.10 & 0.30 & 0 & 1 \\
\hline
\end{tabular}


Based on Table 3 and the descriptive statistics, we can see information about the students' family environments, the characteristics of the students, and the characteristics of the class teacher. Regarding the family environment of the students, the ratio of students with fathers who finished primary school is $70 \%$ and the ratio of students with fathers that completed junior high is $40 \%$. The ratio of students with fathers in agriculture and/or fishery is $63 \%$ and this ratio for the students' mothers is $64 \%$. This means more than half of the students' parents engage in agriculture together. We do not have a clear result for the occupation of about $40 \%$ of parents. Regarding domestic assets, $78 \%$ of all families have a motorcycle, $80 \%$ have a cow, and $95 \%$ have a well.

The total survey sample size is 420 students: 218 boys and 202 girls. The youngest is 7 years old, the oldest is 14 years old, and the average is 9.5 years old (standard deviation 1.17). As we mentioned earlier, because the typical student enters school at 6 years old, the typical third-grade student is 8 years old if he or she does not repeat a grade. However, $27 \%$ of students repeat a grade. Therefore, there are many older students. As for willingness to learn, the ratio of students that complete their homework is $40 \%$ and the ratio of students that frequently ask the teacher questions is $37 \%$.

Twelve of the 13 class teachers are female. The average teacher age is 29 years old, the youngest is 20 years old, and the oldest is 51 years old. There are eight teachers in their $20 \mathrm{~s}$, three in their $30 \mathrm{~s}$, one in her $40 \mathrm{~s}$, and one in his $50 \mathrm{~s}$.

\subsection{Model}

We use the following equation (1) as the educational production function to analyze the factors influencing the students' learning achievements (Glewwe, 2002; Glewwe and Kremer, 2006; Glewwe et al., 2011):

$$
A_{i}=\mathrm{f}\left(H_{i}, \mathrm{~B}_{\mathrm{i}}, \mathrm{S}_{\mathrm{i}}\right)
$$

where $A_{i}$ represents the learning achievement of the student, $H_{i}$ represents the vector of family factors, $\mathrm{B}_{\mathrm{i}}$ represents the vector of student factors, $S_{i}$ represents the vector of school factors, and $i$ represents the student. The educational production function is a function that expresses the relations between the inputs and the outputs of education. The inputs are the family factors and the student factors that explain the demand for education. In addition, there are school factors that explain the supply of education. The output of the education is the educational performance. This performance contains not only cognitive ability such as learning achievements but also noncognitive ability. For this study, we use the learning achievements.

Equation (2) is the model for empirical analysis. Based on equation (1) for the educational production function, we assume this linear model:

$$
\text { Score }_{i}=\beta_{0}+\beta_{1} H_{i}+\beta_{2} B_{i}+\beta_{3} S_{i}+u_{i}
$$

where Score $_{i}$ represents the arithmetic score as the proxy variable of the learning achievements of the student $i$, $\beta_{0} \sim \beta_{3}$ represent the unknown parameters, and $u_{i}$ is the error term.

\section{Results}

Table 4 shows the estimated results by OLS using equation (2). As for the explanatory variables, Model 1 estimates using the family factors, Model 2 estimates using the student factors, Model 3 estimates using the school factors, and Model 4 estimates using all factors.

\begin{tabular}{|c|c|c|c|c|}
\hline & Model 1 & Model 2 & Model 3 & Model 4 \\
\hline Father's educational record & $\begin{array}{l}0.599155^{* * *} \\
(0.1847)\end{array}$ & & & $\begin{array}{l}0.392890^{* *} \\
(0.1926)\end{array}$ \\
\hline Mother's occupation & $\begin{array}{l}0.082229 \\
(0.1696)\end{array}$ & & & $\begin{array}{l}-0.200111 \\
(0.1974)\end{array}$ \\
\hline Number of siblings & $\begin{array}{l}-0.287058 \\
(0.4192)\end{array}$ & & & $\begin{array}{l}-0.441275 \\
(0.4201)\end{array}$ \\
\hline Domestic asset (motorcycle) & $\begin{array}{l}1.124715^{*} \\
(0.5901)\end{array}$ & & & $\begin{array}{l}0.796604 \\
(0.6415)\end{array}$ \\
\hline Domestic asset (cow) & $\begin{array}{l}0.691372 \\
(0.6632)\end{array}$ & & & $\begin{array}{l}1.384177^{*} \\
(0.7417)\end{array}$ \\
\hline Drinking water (well) & $\begin{array}{l}0.994121 \\
(1.3659)\end{array}$ & & & $\begin{array}{l}1.452813 \\
(1.3451)\end{array}$ \\
\hline Housework time per day & $\begin{array}{l}0.616476^{* *} \\
(0.2994)\end{array}$ & & & $\begin{array}{l}0.424606 \\
(0.3330)\end{array}$ \\
\hline
\end{tabular}

Table 4. Determinants of learning achievements 


\begin{tabular}{|c|c|c|c|c|}
\hline \multirow[t]{2}{*}{ Commute time to school } & $-2.033393 * * *$ & & & $-2.045104 * * *$ \\
\hline & $(0.6997)$ & & & $(0.6999)$ \\
\hline \multirow[t]{2}{*}{ School supplies (textbook) } & 2.109429 & & & 1.437282 \\
\hline & $(2.2014)$ & & & $(2.1377)$ \\
\hline \multirow[t]{2}{*}{ Age } & & $-0.362018^{*}$ & & $-0.416437^{*}$ \\
\hline & & $(0.1983)$ & & $(0.2255)$ \\
\hline \multirow[t]{2}{*}{ Enrollment age } & & $0.860358 *$ & & $1.083309^{*}$ \\
\hline & & $(0.4971)$ & & $(0.5818)$ \\
\hline \multirow[t]{2}{*}{ Homework completion } & & $1.421144 * * *$ & & $1.728332 * * *$ \\
\hline & & $(0.4355)$ & & $(0.4662)$ \\
\hline \multirow[t]{2}{*}{ Questions to ask } & & $1.491344 * * *$ & & $1.587867 * *$ \\
\hline & & $(0.5743)$ & & $(0.8037)$ \\
\hline \multirow[t]{2}{*}{ BaN dummy } & & & 0.663581 & 0.035925 \\
\hline & & & $(0.9048)$ & $(1.0097)$ \\
\hline \multirow[t]{2}{*}{ PrA dummy } & & & $2.089964 * * *$ & 1.234592 \\
\hline & & & $0.7796)$ & $(0.9499)$ \\
\hline \multirow[t]{2}{*}{ TaK dummy } & & & 1.089901 & 1.899784 \\
\hline & & & $(0.8522)$ & $(1.1723)$ \\
\hline \multirow[t]{2}{*}{ PrE dummy } & & & $2.235376^{* * *}$ & $3.103163 * * *$ \\
\hline & & & $(0.8089)$ & $(0.9811)$ \\
\hline \multirow[t]{2}{*}{ KnA dummy } & & & $1.682461^{*}$ & 1.147917 \\
\hline & & & $(0.9060)$ & $(1.0822)$ \\
\hline \multirow[t]{2}{*}{ KhN dummy } & & & $2.171533 * *$ & 1.373849 \\
\hline & & & $(0.9377)$ & (1.1549) \\
\hline \multirow[t]{2}{*}{ 2016-year dummy } & $-1.889470 * * *$ & 0.138225 & $-0.943687 *$ & -0.912959 \\
\hline & $(0.5184)$ & $(0.5969)$ & $(0.4837)$ & $(0.8671)$ \\
\hline \multirow[t]{2}{*}{ Constant } & $7.546049 * *$ & $5.969893 * *$ & $9.921090 * * *$ & 1.924605 \\
\hline & $(3.1892)$ & $(2.9691)$ & $(0.6481)$ & $(4.1308)$ \\
\hline Obs & 354 & 382 & 420 & 333 \\
\hline $\mathrm{R}^{2}$ & 0.10 & 0.07 & 0.03 & 0.20 \\
\hline Adjusted $\mathrm{R}^{2}$ & 0.08 & 0.05 & 0.01 & 0.15 \\
\hline
\end{tabular}

Note. In the school dummy, MeB is the reference school. Significance level based on $p$ value represents $* * * 1 \%, * * 5 \%, * 10 \%$. The value in parentheses is the Standard Error.

In Model 4, the significant family factors of learning achievements are the educational background of father, domestic assets (i.e., a cow), and the student's commute time to the school. The significant student factors are age, enrollment age, frequency of homework completion, questions to ask in class, and the school dummy of PrE.

\subsection{Family Factors}

Family factors played a significant role in the learning process of the students. First, the educational background of a student's father had a meaningful influence on the learning achievements of that student. The parental education is one factor of the intergenerational transfer of human capital. The average primary school completion rate of the fathers is $70 \%$, and the rate of primary school non-completion is $30 \%$. The educational system in Cambodia collapsed for the period of civil war in 1970-93, so the last parental generation was not sufficiently educated. However, for about 20 years after the civil war, the educational background of the father influenced the intergenerational transfer of human capital. However, we found no significant result regarding the effect that the mother's occupation has on the learning achievements of the student. In the survey, we asked for the occupations of both the father and the mother. $63 \%$ of the fathers and $64 \%$ of mothers engaged in agriculture and/or fishery. There is a high correlation coefficient of 0.62 between these numbers. If we include them in the explanation variables at the same time, multi-collinearity characteristics are possible. For this reason, we use only the mother's occupation as the explanation variable.

Second, the domestic assets (i.e., a cow) have an equilateral influence on the learning achievements. The domestic assets are indices that express domestic economic conditions. Here, we use a motorcycle and a domestic animal (a cow) as domestic assets. According to Model 1, the motorcycle is a significant variable too. In the rural area, the motorcycle is an indispensable tool for mobility. In addition, while in many cases the farmhouses breed pigs and cocks to sell, the cow is a means of transport, farming and compost production, and it represents a significant means of savings. This result represents the influence of domestic economic conditions on the children's learning achievements. 
The source of domestic drinking water (i.e., a well) is also a part of domestic assets; however, we cannot get a clear result for this factor's influence. The reason may be that $95 \%$ of the students have access to a well as the source of drinking water, and the students can maintain a state of good health if they have access to hygienic water. Health conditions may affect students' learning achievements (Karlan \& Appel, 2011). In rural Cambodia, many families save rainwater in big bottles and use it for drinking and cocking. However, the water saved in these bottles easily decays in hot and humid Cambodia, and can cause health deterioration.

Third, the commute time to school has a significant negative influence on learning achievements. Learning achievements are higher for students who live near their school, which is an intuitive result. If a student's commute time is long, it has negative effects on his or her body and willingness to learn.

Another factor for the learning environment is the amount of time a student spends on housework. Though we do not have a meaningful result for this in Model 4, it is a significant equilateral coefficient in Model 1. In rural villages, the children's housework often consists in caring for cows. If the time spent on this housework increases, the learning time at home decreases, which is expected to negatively influence learning achievements. On the other hand, children participating in housework positively are expected to have a strong willingness to learn. As for the possession of textbooks, since $96 \%$ of the students have one, this is not a meaningful variable for the learning achievements.

\subsection{Student Factors}

The first student factor we examined was the age of the student, which had a significant negative influence on the learning achievements. The enrollment age had significant equilateral influence. Older students, even in the same grade, scored lower on the test. However, scores were still high when these older ages were caused by delays in enrollment. These scores were sometimes lower when the older ages were caused by repeating the same grade. On the survey, we asked about the experience of repeating the same grade. As a result, we found an equilateral correlation of 0.35 between ages and repeating grades. It follows that we exclude the repeating dummy from the explanation variable. In addition, the correlation coefficient between age and enrollment age is only 0.06 , and the correlation coefficient between enrollment ages and repeating a grade are only 0.05 . Even if students experience a delay in entering school, they do not always repeat a grade, but rather may increase their learning achievements.

Second, both the frequency of homework completion and the questions to ask in class have significant equilateral effects on learning achievements. These results are intuitive. A student who does homework more often has 1.7 points higher than a student who does not do homework. In addition, a student asking frequently the teacher questions is higher by 1.6 points than a student who does not ask questions. Such students have a high willingness to learn and high scores for learning achievements. The results are consistent with the assertion of Glewwe et al. (2011) that a teacher giving homework leads to higher scores. The frequency of homework completion may be related to not only the student's willingness to learn but also the domestic educational environment.

\subsection{School Factors}

In Model 3, the PrA, PrE, KnA, and KhN dummies are significant positive coefficients. In Model 4, the PrE dummy is a significant positive coefficient. From these results, we can see that the learning achievements of these primary schools are significantly higher than MeB. However, we treat only the school dummies as the variable of school factors. Therefore, it is not clear what school factors influence the differences.

\subsection{Clarified Characteristics}

The above results show several points. First, the educational background of the father, the domestic assets (i.e., a cow), and the commute time to school are significant family factors that influence the learning achievements. In an LDC such as Cambodia where economic development is low, high economic disparity between families has a considerable influence on learning achievements. Second, learning achievements are influenced by student factors such as age, enrollment age, frequency of homework completion, and questions to ask in class. The students' willingness to learn, which has not been conventionally examined to a significant extent, has an influence even in primary schools in developing countries. Third, though school factors have a meaningful influence on learning achievements, it is not clear which of these factors are important. The difference in the teacher's educational career, ability to teach, and expertise may be important, but we do not have straightforward evidence for this. 


\section{Discussion}

\subsection{School Factors Revisited}

On the survey, we asked about items such as the characteristics of the school facilities and the teacher. However, we could not to use these variables because we got almost the same responses about each item from all primary schools and teachers. The only difference we know of between the schools is that in the school group (clusters), PrA is in the center of the cluster and the other schools are satellites. It follows that we must pay attention to the following points for the difference in learning achievements between schools.

First, we cannot confirm the significant effects that class size has on learning achievements. There is a clear difference in class size between schools on the survey. However, from Table 1 we understand that PrA (2015) has a high number of students in one class but the average score is high. On the other hand, KnA (2015) has a small number of students in one class, but the average score is not so high. For this reason, it is hard to think that class size has a clear effect on learning achievements. This result is consistent with the assertions of Glewwe et al. (2011).

Second, the survey responses do not sufficiently clarify the teachers' methods, use of materials, or quality. Even if the home environment and the school facilities are the same, learning achievements are affected by teaching methods and teacher quality. Therefore, there are two important points to consider.

One is the problem of teacher quality (the teacher's educational background, career, and expertise). In 2016, new teachers took over the classes of expert teachers in PrA and $\mathrm{BaN}$, where the average scores were high in 2015. Consequently, the average scores deteriorated 7.1 points and 4.7 points (respectively) in each school during this period. According to Glewwe et al. (2011), the teachers' subjective knowledge, educational background, and teaching career all influence the students' learning achievements.

The other point is that in some schools two grades are combined into one class. While there are six grades in $\mathrm{MeB}$ and the average score is low, there are only three teachers. Therefore, one teacher teaches two grades at the same time in the same class. There are two blackboards in the classroom, one in the front and one in the back. The third-grade students look at the blackboard in the front and the fifth-grade students look at the blackboard in the back. However, according to Glewwe et al. (2011), the influence that combined classes have on learning achievements is not clear. The reason is that these classes may improve the learning achievements of both sets of students because the upper-grade students teach the lower-grade students.

\subsection{Comparison with Previous Studies}

Our results are consistent with those of Baker et al. (2002) and Wößmann (2010), who conclude that family factors influence learning achievements. Our results are also consistent with the specific factors they name: the educational background of the parents and the family income. In rural Cambodia, which is classified as an LDC, factors such as the educational background of the father, domestic assets (i.e., cows) and commute time to school have meaningful effects on learning achievements. Our finding that the parents' occupations do not influence learning achievements is consistent with Wößmann (2010).

We found that there is a significant difference in the learning achievements among the primary schools, depending on the school factors explained by Heyneman \& Loxley (1983) and Tomita \& Murota (2010). However, there were no clear results regarding the specific factors (class size and teacher quality) considered by Glewwe (2002) and Glewwe et al. (2011).

In previous studies, student factors have hardly been examined, especially regarding the influence that willingness to learn has on learning achievements. However, our findings confirm that the questions to ask in class and homework completion have significant effects on learning achievements. The student's age and enrollment age also have meaningful influences. According to Wößmann (2010), these factors have different influences in Argentina and Colombia.

\section{Conclusion}

In this article, we examine the determinants of learning achievements in Cambodian primary schools, using empirical analysis of survey data from seven schools in the Siem Reap Province.

The main conclusions of this article are as follows. Both student factors and family factors influence the learning achievements of students in Cambodian primary schools. The student factors include the student's age, enrollment age, frequency of homework completion, and questions to ask in class. Our analytical contribution is clarifying what influences the student factors have on learning achievements. The meaningful family factors are the father's educational background, the domestic assets (i.e., cows), and the student's commute time to school. 
We confirm that school factors influence learning achievements, but do not have clear results regarding what school factors have concrete influence.

Finally, we propose a future opportunity for research. This opportunity is to clarify the school factors, which we analyzed only as a school dummy. It is necessary to investigate teaching methods, how to use teaching materials, and teacher quality (educational background, teaching career, and expertise) concretely, and analyze these factors' relations to learning achievements.

\section{References}

ADB. (2015). Key Indicators for Asia and the Pacific 2015. Manila: ADB. Retrieved from http://www.adb.org/publications/key-indicators-asia-and-pacific-2015

Ammermüller, A., Heijke, H., \& Wößmann, L. (2005). Schooling Quality in Eastern Europe: Educational Production during Transition. Economics of Education Review, 24, 579-599. https://doi.org/10.1016/j.econedurev.2004.08.010

Baker, P., Goesling, B., \& Letendre, G. (2001). Socioeconomic Status, School Quality, and National Economic Development: A Cross-National Analysis of the "Heyneman-Loxley Effect" on Mathematics and Science Achievement. Comparative Education Review, 46(3), 291-312. https://doi.org/10.1086/341159

Glewwe, P, Hanushek, E., Humpage, S., \& Ravina, R. (2011). School Resources and Educational Outcomes in Developing Countries: A Review of the Literature from 1990 to 2010. NBER Working Paper, 17554. Retrieved from http://www.nber.org/papers/w17554.pdf

Glewwe, P. (2002). Schools and Skills in Developing Countries: Education Policies and Socioeconomic Outcomes. Journal of Economic Literature, 40, 436-482. https://doi.org/10.1257/jel.40.2.436

Glewwe, P., \& Kremer, M. (2006). Schools, Teachers, and Education Outcomes in Developing Countries. In E. A. Hanushek \& F. Welch (Eds.), Handbook of the Economics of Education (Vol. 2, pp. 945-1017). Amsterdam: North-Holland. https://doi.org/10.1016/S1574-0692(06)02016-2

Hanushek, E. (1995). Interpreting Recent Research on Schooling in Developing Countries. World Bank Research Observer, 10(2), 227-246. https://doi.org/10.1093/wbro/10.2.227

Heyneman, S., \& Loxley, W. (1983). The Effects of Primary-School Quality on Academic Achievement across Twenty-Nine High- and Low-Income Countries. American Journal of Sociology, 88(6), 1162-1194. https://doi.org/10.1086/227799

Karlan, D., \& Appel, J. (2011). More Than Good Intention: Improving the Ways the World's Poor Borrow, Save, Farm, Learn, and Stay Healthy. New York: Dutton.

Ministry of Education, Youth and Sport. (2015). Education Statistics and Indicators 2014-2015. Phnom Penh: Ministry of Education, Youth and Sport. Retrieved from http://www.moeys.gov.kh/en/emis/1607.html

Royal Government of Cambodia. (2003). Education for All National Plan 2003-2015. Phnom Penh: Royal Government of Cambodia. Retrieved from http://datatopics.worldbank.org/hnp/files/edstats/KHMefa03a.pdf

Tomita, M., \& Murota, H. (2010). Factors Influencing Pupils' Learning Achievements: From an MALP Survey in Malawi. Journal of International Development Studies, 19(1), 67-79. Retrieved from https://www.jasid.org/uploads/ckfinder/files/jasid_journal_19-1final.pdf

UNESCO Institute for Statistics. (2015). UIS.Stat. Retrieved from http://data.uis.unesco.org

United Nations. (2000). United Nations Millennium Declaration. New York: United Nations. Retrieved from $\mathrm{http} / / / \mathrm{mdgs} . u n . o r g / \mathrm{unsd} / \mathrm{mdg} /$ Resources/Static/Products/GAResolutions/55_2/a_res55_2e.pdf

United Nations. (2015). The Millennium Development Goals Report. New York: United Nations. Retrieved from http://mdgs.un.org/unsd/mdg/Resources/Static/Products/Progress2015/English2015.pdf

World Bank. (2015). World Development Indicators. Retrieved from http://data.worldbank.org/data-catalog/world-development-indicators

Wößmann, L. (2010). Families, Schools and Primary-School Learning: Evidence for Argentina and Colombia in an International Perspective. Applied Economics, 42(21), 2645-2665. https://doi.org/10.1080/00036840801964617 


\section{Copyrights}

Copyright for this article is retained by the author(s), with first publication rights granted to the journal.

This is an open-access article distributed under the terms and conditions of the Creative Commons Attribution license (http://creativecommons.org/licenses/by/4.0/). 